\title{
Nottingham Grade 2
}

National Cancer Institute

\section{Source}

National Cancer Institute. Nottingham Grade 2. NCI Thesaurus. Code C138988.

Total Notting ham scores of 6 or 7 . 